\title{
EDITORIAL
}

\section{The BEPS 2.0 Project Over the Coming Months}

This editorial was written on the morning of 24 June 2020, just under one week after the Financial Times broke the news that the US Treasury Secretary had written to four finance ministers in Europe telling them that the discussions at the OECD on taxation of the digitized economy (sometime referred to as the 'BEPS 2.0 Project') had reached an impasse, and the US could not agree with the proposals for Pillar 1 of that Project. The date of writing is recorded since, by the time this editorial is being read, it is possible (though unlikely, for reasons discussed below) that US policy will have changed once again. One of the current problems - which must have senior tax officials in many other countries tearing their hair out (if they have any left) - is the instability in US international tax policy, particularly at the present moment. In the last few days, European finance ministers have declared that discussions should continue with regard to seeking agreement on BEPS 2.0, and the US has indicated that it will participate in those discussions.

If one stands back for a moment, however, it is not in fact very surprising that the US should declare that it could not presently participate in any agreement on Pillar 1 , which seeks to reallocate part of the profits of multinational enterprises ('MNEs') in the direction of the market economies. This is an election year in the US, and by all accounts the election will be both heated and closerun. Realistically, the original deadline of June 2020 for reaching agreement on taxation of the digitized economy was the latest time that it might have been possible to get the current US administration on board before election concerns took over. However, delays in making progress, and the impact of the Covid-19 virus, made agreement in June impossible. The postponed date for agreement by October 2020 was never likely to be achievable: the US will be completely immersed in the election by that stage. Realistically, it will be well into the first quarter of 2021 before an agreement is likely. ${ }^{1}$ Even if there is no change at the top of the US administration, other personnel are likely to change. If there is a change in the US president, it will take perhaps months before new personnel are in place and a decision has been taken about policy on international tax reform.

This was predictable. The timing of the US election in November meant that agreement by the end of 2020 was illusory once it had been decided to postpone past June. There is also experience of this in the past. In 2000 the Harmful Tax Practices project of the OECD ran into the same problems of the US election cycle. It was by no means clear what position the incoming Bush administration would take, and it was not until well into 2001 that personnel had been appointed and the administration took a position. When it did, support for the project was conditioned on a fundamental change in the focus, which effectively diverted the OECD's work in a different direction. It is entirely possible that the same thing will happen with the BEPS 2.0 project.

The US has indicated that agreement on Pillar 2 (the minimum global tax element) might be possible by October. However, even assuming that were correct and agreement is possible on Pillar 2, one wonders how attractive that option would be. Many countries see Pillar 1 and Pillar 2 as a package, with Pillar 1 achieving a reallocation of taxing jurisdiction in favour of market economies. By offering agreement on Pillar 2, the US is not really offering anything since the US position is that the existing US GILTI provisions meet the Pillar 2 Globe requirements and should be grandfathered. Put another way round, agreement on Pillar 2 looks like it amounts to the US doing nothing, and not participating further in a solution to the taxation of the digitized economy. It also makes agreement on Pillar 1 less likely because there is no longer any element of a package and there is no scope for tradeoffs.

\section{Notes}

Given that agreement by the end of 2020 was never likely once June had past, one is entitled to ask why October 2020 was ever considered as a possible deadline. One reason is the G20 meeting presently scheduled for Saudi Arabia in November 2020. However, it is more than likely that this meeting - if it goes ahead - will be focusing on issues arising from the Covid-19 pandemic, the economic recession, and rising international tensions particularly between the US and China (but also China and India). International tax was never likely to be high on the agenda of that meeting, and it may be hard enough for the OECD to even get sufficient attention to secure a new mandate from the G20.The end of 2020 is, of course, the date by which some European finance ministers have called for agreement on a multilateral solution to the taxation of the digitized economy if they are to defer implementation of digital service taxes ('DSTs'). However, the Covid-19 pandemic should, in principle, provide adequate political cover for a reasonable postponement of the deadline until, say the middle of 2021 for reaching agreement. 
Putting these points together, it is reasonable to conclude that the BEPS 2.0 project is now effectively in suspense (or, if one likes, on furlough) until the end of the first quarter of 2021. Some work might continue on detailed issues, but no package deal is likely until well into next year. This editorial considers some of the implications of that pause in the Project.

Before doing so, some further comments might be made about Secretary Mnuchin's letter.

The manner in which the US walked out of the BEPS 2.0 discussions - if 'walk out' is quite the right expression - is itself of interest. Treasury Secretary Mnuchin's letter to the four European finance ministers was sent around 12th June. It seems probable that drafts of the letter were circulating one or two days before, and that the OECD leadership were aware of this. Despite the fact that the US had indicated its intention not to continue discussions with regard to an agreement on Pillar 1, a meeting of the steering group of the Inclusive Framework went ahead on fifteenth, with only some members having received the Treasury Secretary's letter. It must have been a rather surreal meeting, with some participants privy to the US letter and others not. After the close of the meeting, the Financial Times reported the US position.

In principle, one assumes that the US delegation at the meetings could simply have stated that, because of the combination of the pandemic and the forthcoming US elections, it would propose a postponement of the deadline for reaching agreement until into 2021. That would have been a less combative and potentially more constructive approach. As an outside spectator, therefore, one is entitled to ask why the US Treasury Secretary wrote in the way that he did about the Pillar 1 proposals. One is tempted to think that the reasons have much to do with US domestic politics. A dispute with European governments over a tax proposal that could be seen as adversely impacting a number of US national champion MNEs might go down well in a US reelection campaign. The Mnuchin letter needs to be seen, therefore, in the context of a threatened trade war and the imposition of retaliatory tactics by the US if a number of countries - not all of them European - go ahead with their proposed digital service taxes (or 'DSTs').

From the point of view of US politics, a threatened trade war with Europeans to protect national champion businesses against European taxation might be seen positively. From the point of view of a world economy trying desperately to recover from the pandemic and slipping into a worldwide recession, a trade confrontation is the last thing one would want at this time. It is a particularly pointless conflict given that virtually everyone accepts that the rules for taxation of the digitized economy need to be revised, and the only real dispute is the methodology to be employed. In those circumstances, it would make immense sense if the countries that have enacted DSTs (or have announced their plans to do so unless international agreement is reached by the end of 2020) came out and agreed a postponement of the deadline for international agreement. Some of those countries have already agreed not to collect DST if agreement is reached by the end of this year; many other countries have deferred tax collections widely because of the coronavirus. Recognising the inevitable (that agreement is not going to be reached by the end of this year), it would make immense sense for those countries to agree to postpone collection of any DST pending agreement on a multinational solution to the taxation of the digitized economy by 1 July 2021 (let us say). From the point of view of countries that have presently set the end of 2020 as a deadline, this would mean displaying an element of flexibility, but the current pandemic circumstances justify it (even if the US election did not of itself justify it). Strangely enough, if it is the US that wants to be seen to be spoiling for a fight, then it may be the US administration that is least attracted by the idea of a postponement of deadlines as it takes away justification for a potential trade conflict. However, from the point of view of sensible international politics, it makes a great deal of sense.

A curious aspect of any threatened trade war over the imposition of taxes on digital services is that there seems to be general agreement that something has to be done about the taxation of the digitized economy. The current international tax rules do not cope well with digitized businesses, not least because of the emphasis on physical presence in a country to justify taxation of business profits. There also seems general agreement that a multilateral solution to this problem is preferable to unilateral action. However, in the absence of a multilateral solution a number of countries have adopted or are proposing to adopt various forms of taxes on the supply of digital services. Given the virtual impossibility of taxing the profits of business in those sectors because of the current international rules, what is left is the rather blunt instrument of taxes on gross turnover. Those risk causing damage to the businesses and creating unrelieved double taxation and are clearly a second best, if not third best, alternative. However, in the absence of international agreement they may be all that countries can adopt to deal with taxation of large multinationals operating in the digitized sector.

One of the themes of this editorial is that a delay in agreement on BEPS 2.0 was inevitable and unavoidable once the pandemic meant that agreement could not be reached by June. If nothing else, the US election cycle has this effect. Given that is the position (and assume that it does not change before this editorial appears) the question is what the OECD might do about it. Far be it from the author to suggest to the leadership at the Centre for Tax Policy and Administration what they might be planning to do, but perhaps it is appropriate to float a couple of suggestions for consideration.

First, take a break. Some of the people at the CTPA have been working on BEPS since the first discussion at 
the first away-weekend in 2012. The pace has been frantic, and an enforced pause for refreshment and reflection would be advantageous. For reasons mentioned above, trying to get agreement on Pillar 2 in the next few months may be pointless and undesirable. If it is open to tourists, take some time and visit Lake Como.

Secondly, the enforced furlough should be seen as an opportunity to rethink issues and priorities. The BEPS project began in 2013 with only a vague notion of what the problem was in terms of the taxation of MNEs, and with some thoughts about possible remedies, some of which had relatively little to do with base erosion or profit shifting but were simply items sitting on the agenda that had not progressed very fast (for example, some of the work on treaty abuse has little to do with base erosion or profit shifting). Now is the opportunity in light of the greater knowledge and experience gained over the last eight years to reassess both problems and possible solutions. If this process of reflection and reassessment is to be a valuable process, it has to be a completely unrestricted process. It should be possible, for example, to conclude that maybe base erosion wasn't the problem that originally it was thought to be, or that some of the proposed solutions are ineffective or unworkable.

One aspect of this reflection and reconsideration might usefully be a detailed discussion of the tax planning strategies adopted by a number of large MNEs (and not just those headquartered in the US). When the BEPS project started there was an element of general concern about the low effective tax rates reported by some of these MNEs, and particularly their tax contribution in some countries where they were operating. However, there was relatively little detail known about some of those MNE groups and the strategies they were employing. In the last eight years a significantly greater amount of information has become available, partly as a result of parliamentary and congressional enquiries in a number of countries, partly as a result of the European Commission state aid investigations, and partly as a result of the introduction of country-by-country reporting. It should now be possible to put together some pretty comprehensive case studies of how some of the major MNEs have managed their tax exposure both up to the completion of the first round of BEPS 1.0, and in the years since 2016 .

A detailed examination of those case studies is likely to identify a number of key factors. First, the degree to which (if at all) base erosion or profit shifting is a significant problem. Secondly, exactly what measures these MNEs rely upon as part of their tax planning structures: are they relying upon particular provisions of domestic law in certain countries (such as 'check the box' rules, or gaps in CFC rules); are they relying upon provisions in bilateral tax treaties; are they relying upon entities in tax havens; are they relying upon transfer mispricing; or are they relying upon something else that has not even been identified up till now? Third, it might identify which countries are benefitting from these activities, and which are disadvantaged.

This process is best carried out by the OECD because of access to $\mathrm{CbCR}$ and other tax data by Member Countries. However, if the OECD does not itself carry this out, it is a process that could usefully be carried out by academics, possibly bringing together those with different skill sets: those with a background in economics, in accounting, in international tax law, and in domestic tax provisions, to try to understand exactly what is the problem, if there is a problem in the first place. Again, this needs to be a completely open process, willing to conclude that there may, in fact, have been little or no base erosion or profit shifting, or, if there has been management of tax exposure, it may have relied upon provisions that have not been targeted in the BEPS process to date.

One specific area where research would be valuable is to clarify how far multinational businesses operating entirely or very largely in the digitized sector have been able to take advantage of various defects and lacunae in the international tax rules over the last twenty years. On one view, many of the new, national champion businesses (and not just US-based businesses) that have taken great advantage of digitalization have become champions over the last twenty years for exactly this reason that they were able to manage their direct income tax expense and built up large tax-free reserves. The underlying question is how far the failure to remedy defects in international tax rules, both at a domestic, bilateral and multilateral level, have provided an unfair trade advantage which has allowed these national champions to grow in an almost-tax-free environment.

Fourthly, the enforced furlough on the BEPS 2.0 project may also allow the OECD to reconsider more broadly the tax agenda that it has followed over the last eight years and to reassess whether that agenda has identified the right priorities and given them the right amount of attention. There has been some mention recently of a 'Pillar 3', which would focus more on the fiscal interests of developing countries. One of the lessons that is being painfully learnt from the Covid-19 pandemic is the need to increase resources available for healthcare in developing countries, and attention to the fiscal needs of developing countries is particularly timely. Only one thought here: this should be an agenda item all of its own, and not linked to the BEPS project or part of BEPS 2.0. This is not simply an issue of base erosion or profit shifting, but of reviewing the structure of international tax rules, both for direct and indirect taxes and trade taxes, to ensure that they do not disadvantage developing countries. If there is to be at least a nine month pause in the BEPS 2.0 project, then a realignment of resources to focus on this area would be massively welcomed.

One would expect it from the author of this editorial, but consideration should also be given to the issue of taxpayers' rights. If you like, you can refer to it as 'Pillar 4', but what it is called is less important than 
that it is an item on the agenda. Even before the pandemic, confidence in governments was low in many countries, and the pandemic has reduced that confidence further. In the tax administration field, one way of building up and improving the relationship between the taxpayer and tax administrations is to ensure that taxpayers' rights are respected. If, for example, the OECD were implicated in a major loss of taxpayers' confidential data, that would seriously damage further confidence both in tax administrations and in the organization itself. The OECD has been instrumental in putting in place the mechanism for automatic exchange of data for tax purposes, and its reputation is therefore at risk not simply if that mechanism proves to leak, but also if governments lose or misuse the data they have received. That is just one of the examples, but it is a particularly significant example of the moral risk to the organization from not placing taxpayers' rights high enough on the agenda.

A fifth and final issue that the OECD might wish to consider during the nine month enforced furlough is perhaps the most difficult one for any organization. That is to consider whether it is the right organization to be doing the job that it is currently seeking to perform. The impact of the US Treasury Secretary's letter on the BEPS 2.0 process shows how far the OECD tax work is at risk from the US election process. This was the case in 2000; it is the same now. That is not true of every international organization: withholding funds by the US can impact on the work of some other international organizations, but it does not bring that work to an impasse. In very many ways, the OECD as it currently operates is now regularly seen to be the wrong organization to be leading the work on international tax. The enforced furlough would be a good opportunity for the OECD to consider what structural changes are needed - to the organization or to its work with other international bodies if necessary - to remedy this issue going forward.

News of the US Treasury Secretary's letter last week came as something of a shock to some people. However, if one stands back, the probability that work on the taxation of the digitized economy would not move forward over the next nine months was not particularly surprising. The issue now is how to take advantage of this enforced furlough so that it is seen as an opportunity and not as a crisis.

Philip Baker

QC, barrister, Field Court Tax Chambers;

Visiting Professor, Oxford University

Email:pb@fieldtax.com. 